\title{
Distribution of Virus-Infected Bacteria in the Western Equatorial Pacific ${ }^{1}$
}

\author{
Chung Yeon Hwang ${ }^{2}$ and Byung Cheol Cho ${ }^{2,3}$
}

\begin{abstract}
Viruses are generally considered an important agent of bacterial loss in diverse marine environments. However, the impact of viruses on bacteria is unknown in the western equatorial Pacific, where surface waters are warm and phytoplankton biomass is low (i.e., oligotrophic). Further, little is known about their importance in the mesopelagial, where bacteria and heterotrophic nanoflagellates are known to be metabolically active. To elucidate the ecological characteristics of viruses in the western equatorial Pacific, abundances of bacteria and viruses were measured, along with frequencies of visibly infected cells (FVIC) and frequencies of dividing cells (FDC) in epipelagic and mesopelagic samples at three stations near the equator from August to September 2002. Measurements of Secchi depth $(20 \mathrm{~m})$ and chlorophyll $a$ concentrations $(0.07-$ $0.4 \mu \mathrm{g} \mathrm{chl} a$ liter $^{-1}$ ) indicated that the study area was oligotrophic during the investigation. FVIC ranged from $0.4 \%$ to $1.8 \%$ and $0.5 \%$ to $1.8 \%$ in the epipelagic and mesopelagic zones, respectively. Virally induced bacterial mortality was inferred to range from $4.5 \%$ to $20.8 \%$ in the epipelagic zone, suggesting that viruses contribute substantially to bacterial mortality in oligotrophic seawaters. In addition, these values were similar to those estimated for the mesopelagic zone $(5.0 \%-21.2 \%)$. Overall, viruses appear to be an important factor in the loss of bacterial production in both oligotrophic epipelagic and mesopelagic zones in the study area.
\end{abstract}

VIRUSES ARE KNOWN to be an important agent of bacterial mortality in diverse environments (Fuhrman 1999, Wommack and Colwell 2000). However, limited studies are available on the viral mortality of bacteria in oligotrophic environments. In oligotrophic seawaters of the East Sea of Korea and the

1 This work was partly supported by "Multidisciplinary Investigation of the Western Pacific" of the Korea Ocean Research and Development Institute project (PE82400) and by the BK21 project of the Korean Government. Manuscript accepted 25 May 2009.

${ }^{2}$ Molecular and Microbial Ecology Laboratory, School of Earth and Environmental Sciences and Research Institute of Oceanography, Seoul National University, Seoul 151-742, Korea.

${ }^{3}$ Corresponding author (phone: 82-2-880-8171; fax: 82-2-877-9774; e-mail: bccho@snu.ac.kr).

Pacific Science (2010), vol. 64, no. 2:177-186

doi: $10.2984 / 64.2 .177$

(C) 2010 by University of Hawai'i Press

All rights reserved
North Pacific Subtropical Gyre, the impact of viruses on bacteria has been suggested to be important (Hwang and Cho 2002b, Brum 2005), but the viral mortality of bacteria was reported to be very low in the oligotrophic western Mediterranean (Guixa-Boixareu et al. 1999). In the open ocean, many studies have focused on viral ecology in the epipelagial. Only a few studies have examined mesopelagic viruses (Steward et al. 1996, Weinbauer et al. 2003). In the mesopelagic zone, it has been recognized that coupling between sinking particulate organic carbon and free-living bacteria production is tight (Cho and Azam 1988, Simon et al. 1992). In addition, a year-long study in the North Pacific showed that $\sim 76 \%-90 \%$ of all cells at a depth of 200-1,000 m contained significant amounts of rRNA, indicating that most mesopelagic microorganisms are metabolically active (Karner et al. 2001). Furthermore, heterotrophic nanoflagellates, a link between bacteria and microzooplankton, have been suggested to be active and survive well in the 
mesopelagial (Cho et al. 2000, Tanaka and Rassolzadegan 2002). Limited data on the frequency of visibly infected cells (ranging from $0.5 \%$ to $0.7 \%$ ) in the mesopelagial of the North Pacific Ocean, the Mediterranean Sea, and the Chukchi Sea suggest that viruses have an important impact on bacterial losses (Proctor and Fuhrman 1991, Steward et al. 1996, Weinbauer et al. 2003).

The primary goals of this study were to estimate the importance of virally induced bacterial mortality in the epipelagial and mesopelagial of the oligotrophic western equatorial Pacific, where marine viruses have not yet been studied.

\section{MATERIALS AND METHODS}

\section{Study Area}

The study area was located near the Bismarck Archipelago, Papua New Guinea, in the western equatorial South Pacific. During the "Multidisciplinary Investigation of the Western Pacific" cruise, sampling was conducted aboard the RV Onnuri, operated by the Korea Ocean Research and Development Institute from 26 August to 6 September 2002. Three stations (Stn. 1: $152^{\circ} 34.9^{\prime} \mathrm{E}, 3^{\circ} 18.6^{\prime} \mathrm{S}$; Stn. 4: $151^{\circ} 40.0^{\prime} \mathrm{E}, 3^{\circ} 42.9^{\prime}$ S; Stn. 5: $144^{\circ} 39.9^{\prime}$ E, $\left.3^{\circ} 27.9^{\prime} \mathrm{S}\right)$ were occupied at 1200 hours local time on 26 August, 1800 hours on 1 September, and 0100 hours on 6 September, respectively. The bottom depths at Stns. 1, 4 , and 5 were $\sim 1,600 \mathrm{~m}, \sim 2,000 \mathrm{~m}$, and $\sim 1,800 \mathrm{~m}$, respectively. Samples were collected with 10-liter Niskin bottles mounted on a conductivity-temperature-depth (CTD) profiler (SBE 911 plus, Sea-Bird Electronics) rosette from three to six depths in the epipelagial $(3-150 \mathrm{~m})$ and three to four depths in the mesopelagial (300-1,000 m).

\section{Bacterial and Viral Abundance}

Samples for measurement of bacterial abundance and viral abundance were fixed with $0.02 \mu \mathrm{m}$-filtered, borate-buffered formalin (final concentration of $2 \%$ ). The fixativeamended samples were stored at $4^{\circ} \mathrm{C}$ for 28 to 39 days until they could be processed in the land-based laboratory. One to $2 \mathrm{ml}$ of samples were filtered through $0.02 \mu \mathrm{m}$ pore size Anodisc filters (Whatman), and then the filters were placed on a drop of $100 \mu \mathrm{l}$ of diluted SYBR Green I (final dilution, $2.5 \times 10^{3}$-fold [Noble and Fuhrman 1998]) for $15 \mathrm{~min}$ in the dark. Bacteria and viruses were counted in duplicate samples using a blue filter set on an epifluorescence microscope (Olympus model BX60) at $\times 1,250$. Bacteria were easily distinguished from viruses on the basis of their relative size and brightness.

\section{Frequencies of Visibly Infected Cells and Dividing Cells}

Samples for transmission electron microscopy observation were preserved with electron microscopy-grade glutaraldehyde (final concentration of $2 \%$ ) and stored in sterile $50 \mathrm{ml}$ polypropylene centrifuge tubes at $4^{\circ} \mathrm{C}$. Two mesopelagic samples (from 500 to $1,000 \mathrm{~m}$ depth) at each station were fixed as described earlier and stored in $500 \mathrm{ml}$ polycarbonate bottles presoaked with $10 \% \mathrm{HCl}$ and rinsed with deionized water. Formvar-coated, 200mesh electron-microscope grids were made evenly hydrophilic by floating them on a drop of $1 \%$ poly-L-Lysine for 1 min (Suttle 1993). The grids were placed on a flat platform at the bottom of the ultracentrifuge tubes in which subsamples $(9 \mathrm{ml})$ were centrifuged (Beckman XL-90) at 30,000 $\times g$ using a swinging bucket rotor (SW41) for $30 \mathrm{~min}$ at $20^{\circ} \mathrm{C}$. To acquire an adequate amount of bacteria for enumeration from the preserved deeper seawater samples, $9 \mathrm{ml}$ of the samples were centrifuged, and the supernatant was carefully discarded. Then, the same preserved samples were refilled and centrifuged again. This procedure was repeated two (100-300 $\mathrm{m}$ depth samples) to four (500-1,000 $\mathrm{m}$ depth samples) times (i.e., $18-36 \mathrm{ml}$ of each sample was centrifuged on a grid). For two samples (20 and $500 \mathrm{~m}$ ) at each station, duplicate grids were prepared to measure standard deviations of frequency of visibly infected cells (coefficient of variation: $2 \%-15 \%$ and $14 \%-31 \%$ for 
20 and $500 \mathrm{~m}$ samples, respectively). Grids were stained for $20 \mathrm{sec}$ with $0.5 \%$ uranyl acetate followed by three sequential rinses with $0.02 \mu \mathrm{m}$-filtered (Milli-Q) water. Virusinfected cells were enumerated on a transmission electron microscope (JEM-1010, JEOL) at an accelerating voltage of $80 \mathrm{keV}$ (Weinbauer et al. 1993). For each sample, 300500 cells were examined by transmission electron microscopy at 30,000 to $50,000 \times$ magnification and scored as infected if they contained five or more intracellular viruslike particles. Burst size was estimated as the average number of viruslike particles observed in all visibly infected cells. Thus, the burst size in our study may be a minimum estimate (Weinbauer 2004, Parada et al. 2006).

The frequency of dividing cells was simultaneously measured by transmission electron microscope observation (Tuomi et al. 1995). Cells with a clear invagination were considered dividing cells, and $\sim 10-20$ dividing cells per sample were counted.

\section{Estimation of Bacterial Production}

Use of radioisotopes to measure bacterial production (e.g., ${ }^{3} \mathrm{H}$-thymidine, ${ }^{14} \mathrm{C}$-leucine) was strictly prohibited during the cruise. Thus, to obtain estimates of bacterial production for the mixed-layer samples from 3 to 75 $\mathrm{m}$ depth, frequency of dividing cells (FDC) was converted to frequency of dividingdivided cells (FDDC, \%) using the following equation: $\mathrm{FDC}=0.82 \times \mathrm{FDDC}$ (Torréton and Dufour 1996). Growth rate was estimated using the following relationship between FDDC (\%) and growth rate $\left(\mu\right.$, day $\left.^{-1}\right): \mu=$ $0.022 \times(\mathrm{FDDC})^{0.98}$, for water temperature at $\sim 30^{\circ} \mathrm{C}$, obtained from Tuamotu Atoll lagoons (mesotrophic) and the surrounding ocean (oligotrophic), French Polynesia (Torréton and Dufour 1996). Bacterial production was then calculated on the basis of growth rate and bacterial abundance. In this study, seawater temperatures in the mixed layer ranged from 27.3 to $29.1^{\circ} \mathrm{C}$. Below the mixed layer, bacterial production was not estimated using the equation given earlier due to lower seawater temperatures $\left(<26^{\circ} \mathrm{C}\right)$.

\section{Virally Induced Bacterial Mortality}

The frequency of infected cells was estimated from the frequency of visibly infected cells using the average conversion factor of 7.11 that has been established for natural communities (Hwang and Cho 2002a, Weinbauer et al. 2002). Virally induced bacterial mortality was estimated from the frequency of infected cells using a model that assumed (1) a steady state for the bacterial population, in which bacterial growth is balanced by bacterial mortality (Proctor et al. 1993), (2) infected and uninfected cells are grazed at the same rate, and (3) the latent period is equal to the generation time of the bacteria (Binder 1999). The conversion factors and assumptions made in the model should be directly measured or confirmed to accurately assess virally induced bacterial mortality in natural communities (Weinbauer 2004). Thus, the term "inferred virally induced bacterial mortality" was used to indicate the use of general conversion factors for estimating virally induced bacterial mortality in this study.

\section{Other Analyses}

Depth profiles of water temperature and salinity were measured with a CTD profiler. Transparency of the water was measured with a Secchi disk. Analysis of variance (ANOVA) and $t$-tests were carried out using SPSS for Windows (Version 16.0, 2007).

\section{RESULTS}

\section{Hydrography}

The water column at each station was well stratified and the mixed layer was restricted within the upper $70 \mathrm{~m}$ depth at Stns. 4 and 5 , and $90 \mathrm{~m}$ at Stn. 1 (Figure 1). In the mixed layers, temperatures were warm (27.3$29.1^{\circ} \mathrm{C}$ ) and decreased steeply to 7.5 to $9.9^{\circ} \mathrm{C}$ in the upper 400 or $500 \mathrm{~m}$ of the water column. Below those depths, the temperature decreased gradually to 4.3 to $4.5^{\circ} \mathrm{C}$ at 1,000 $\mathrm{m}$ depth at each station (Figure 1). Salinity ranged from 35.3 to 35.9 psu in the mixed layer, peaked (35.9-36.1 psu) between 140 


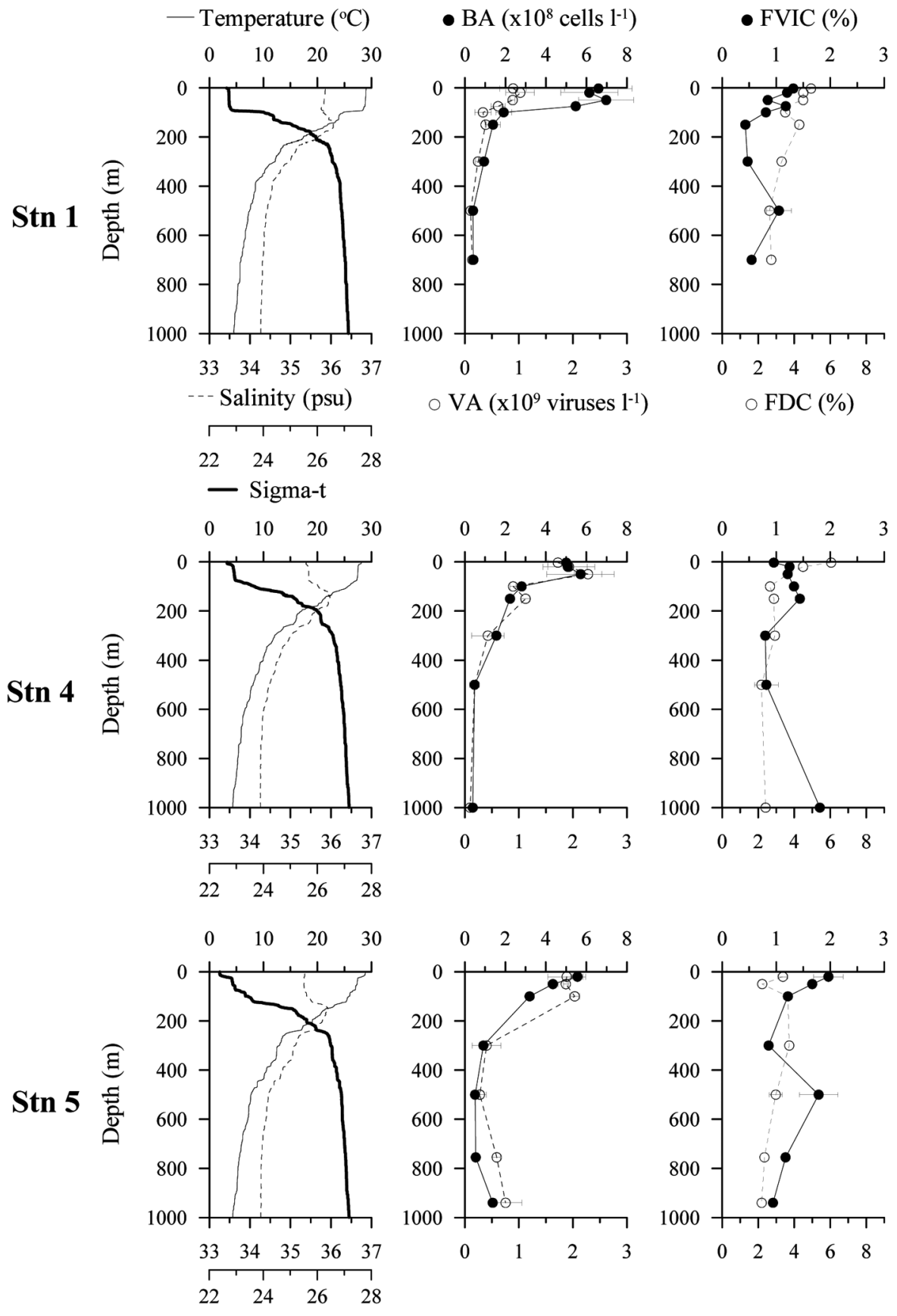

FIGURE 1. Depth profiles of temperature, salinity, sigma-t, bacterial abundance (BA), viral abundance (VA), frequency of visibly infected cells (FVIC), and frequency of dividing cells (FDC) at the study site. BA and VA were measured in duplicate. For FVIC and FDC, six samples (20 and $500 \mathrm{~m}$ at each of three stations) were measured in duplicate, otherwise these are single measurements. When bars are not shown, SD is smaller than the size of the symbol. 


\section{TABLE 1}

Inferred Virally Induced Bacterial Mortality (VBM), Estimated Bacterial Production (BP), and Burst Size in the Epipelagic (3-150 m) and Mesopelagic (300-1,000 m) Zones of the Western Equatorial South Pacific Ocean in August and September 2002

\begin{tabular}{lccccc}
\hline \hline Stn. & Pelagic Zone & $\begin{array}{c}\text { No. of } \\
\text { Samples }\end{array}$ & $\begin{array}{c}\text { VBM } \\
(\%)\end{array}$ & $\begin{array}{c}\text { BP } \\
\left(\times 10^{8} \text { cells liter }^{-1} \text { day }^{-1}\right)\end{array}$ & $\begin{array}{c}\text { Burst Size } \\
\text { (Viruses) }\end{array}$ \\
\hline 1 & Epi & 6 & $10.7 \pm 3.9$ & $0.7 \pm 0.2^{a}$ & $17 \pm 4$ \\
& Meso & 3 & $8.4 \pm 5.2$ & ND & $16 \pm 3$ \\
4 & Epi & 5 & $13.9 \pm 2.2$ & $0.6 \pm 0.1^{a}$ & $16 \pm 3$ \\
& Meso & 3 & $15.8 \pm 6.4$ & ND & $16 \pm 3$ \\
5 & Epi & 3 & $17.9 \pm 3.8$ & $0.4 \pm 0.2^{a}$ & $17 \pm 1$ \\
& Meso & 4 & $12.4 \pm 3.3$ & ND & $16 \pm 1$ \\
\hline
\end{tabular}

Note: Values are mean \pm SD. ND, no data.

${ }^{a}$ Data from the mixed layer: $0-90 \mathrm{~m}$ at Stn. 1 and $0-70 \mathrm{~m}$ at Stns. 4 and 5.

and $150 \mathrm{~m}$, and decreased to $34.3 \mathrm{psu}$ at 1,000 $\mathrm{m}$ depth (Figure 1).

\section{Vertical Profiles of Bacteria and Virus Abundance}

Depth profiles of bacterial abundance and viral abundance were similar among Stns. 1, 4, and 5 (Figure 1). Maximum bacterial abundance $\left(5.7-7.0 \times 10^{8}\right.$ cells liter $\left.^{-1}\right)$ and viral abundance $\left(1.0-2.3 \times 10^{9}\right.$ viruses liter $\left.^{-1}\right)$ were found in the mixed layer, and bacterial abundance and viral abundance gradually decreased with depth below $100 \mathrm{~m}$. However, slight increases in bacterial abundance and viral abundance were observed in the lower part of the mesopelagic zone at Stn. 5 (Figure 1). At all stations, bacterial abundance (0.4$1.6 \times 10^{8}$ cells liter $^{-1}$ ) and viral abundance $\left(0.1-0.8 \times 10^{9}\right.$ viruses liter $\left.^{-1}\right)$ in the mesopelagic zone were lower (on average, five- to ninefold and four- to sevenfold for bacterial abundance and viral abundance, respectively) than in the epipelagic zone (Figure 1).

\section{Frequency of Dividing Cells and Bacterial Production}

Frequency of dividing cells in the mixed layer was lowest at Stn. $5(2.8 \% \pm 0.8 \%)$ occupied at midnight (Figure 1); however, at Stns. 1 and 4 occupied during the day, it ranged from $3.5 \%$ to $6.1 \%$ (Figure 1). Bacterial pro- duction ranged from 0.3 to $0.8 \times 10^{8}$ cells liter $^{-1}$ day $^{-1}$ in the mixed layer (Table 1).

\section{Frequency of Visibly Infected Cells, Virally Induced Bacterial Mortality, and Burst Size}

In the epipelagic zone, frequency of visibly infected cells (FVIC) varied from $0.4 \%$ to $1.8 \%$ (Figure 1), with higher FVIC values at Stn. $5(1.6 \% \pm 0.3 \%)$ than at Stns. 1 and 4 $(0.8 \%-1.3 \%)$. The range of FVIC in the mesopelagic zone $(0.5 \%-1.8 \%)$ was similar to that in the epipelagic zone (Figure 1). A subsurface peak of FVIC was observed in the mesopelagic zone at each station $(500 \mathrm{~m}$ at Stns. 1 and 5, and 1,000 $\mathrm{m}$ at Stn. 4 [Figure 1]). Virally induced bacterial mortality inferred from the FVIC values was $4.5 \%-$ $20.8 \%$ and $5.0 \%-21.2 \%$ in the epipelagic and the mesopelagic zones, respectively. Burst size was on average 17 (range: 14-24) and 16 (range: 13-19) in the epipelagic and mesopelagic zones, respectively (Table 1 ).

\section{DISCUSSION}

Certain lines of evidence suggested that the study area was oligotrophic during the investigation: the Secchi depth was $20 \mathrm{~m}$ at Stn. 1 (seawater with a Secchi depth greater than 16 $\mathrm{m}$ is regarded as oligotrophic [Morita 1997]), and chlorophyll $a$ (chl $a$ ) concentrations measured in the vicinity of the stations during 
this investigation varied from 0.07 to $0.4 \mu \mathrm{g}$ chl $a$ liter $^{-1}$ (Lee 2003).

The frequency of visibly infected cells values $(1.2 \% \pm 0.3 \%)$ obtained from the epipelagic zone in this oligotrophic study area were comparable with those in oligotrophic epipelagic waters of the East Sea during the summer $(1.2 \%-2.2 \%$ [Hwang and Cho $2002 b]$ ) and in oligotrophic epipelagic waters of the northwestern Mediterranean Sea during the summer $(1.4 \%-1.5 \%$ [Weinbauer et al. 2003]). In particular, the frequency of visibly infected cells values $(1.3 \%-1.8 \%)$ found in the oligotrophic epipelagial at Stn. 1 confirmed that virus-infected bacteria might be measurable $(1.2 \%-2.2 \%)$ in oligotrophic seawaters, as previously suggested (Hwang and Cho 2002b, Weinbauer et al. 2003).

Recently, the effects of storage on frequency of visibly infected cells in preserved seawater samples were evaluated for a long-term storage period $\left(4^{\circ} \mathrm{C}\right.$ for 1 month [Hwang and Cho 2008]). The frequency of visibly infected cells values after storage either decreased or varied slightly with storage time for coastal and offshore samples. The inferred virally induced bacterial mortality based on the frequency of visibly infected cells values at the end of storage varied from $45.5 \%$ to $192.7 \%$ of that estimated using the frequency of visibly infected cells values at the beginning of storage (Hwang and Cho 2008). Likewise, there may have been some changes in frequency of visibly infected cells values during storage in the study reported here. If a similar degree of storage effects was assumed $\left(4^{\circ} \mathrm{C}\right.$ for $28-39$ days), the inferred virally induced bacterial mortality could range from $3.8 \%$ to $34.5 \%$ rather than $8.4 \%-17.9 \%$ (Table 1). The contribution of viruses to bacterial losses in the study area could thus be somewhat affected by longterm (i.e., 1 month) storage effects.

To compare virus production based on inferred virally induced bacterial mortality with other studies of oligotrophic seawaters, virus production in the study reported here was estimated by multiplying together burst size, inferred virally induced bacterial mortality, and bacterial production estimates (Noble and Steward 2001). Bacterial production estimates $\left(0.3-0.8 \times 10^{8}\right.$ cells liter $^{-1}$ day $^{-1}$ [Table 1]) in our study were comparable with those reported for the western equatorial $\mathrm{Pa}$ cific $\left(0.2-2.0 \times 10^{8}\right.$ cells liter ${ }^{-1}$ day $^{-1}$ by the ${ }^{3} \mathrm{H}$-thymidine incorporation method [Shiah et al. 1998]). It is interesting that virus production estimates $\left(1.1 \pm 0.7 \times 10^{8}\right.$ viruses liter $^{-1}$ day $\left.^{-1}\right)$ in our study were also comparable with those for the oligotrophic Mediterranean Sea $\left(0.8-0.9 \times 10^{8}\right.$ viruses liter ${ }^{-1}$ day $^{-1}$ [Weinbauer et al. 2003]), a study that directly measured bacterial production using a radioisotope incorporation method. Burst size used to estimate virus production in our study was measured as the average number of viruses observed in all visibly infected cells. However, the number of viruses within an infected cell might continue to increase before bursting the cell. Parada et al. (2006) found that the minimum estimates of burst size employed in the study reported here were 1.4fold lower than the maximum estimates of burst size. Thus, virus production estimates in our study may be somewhat underestimated. The burst sizes in this study $(16 \pm 2$ [Table 1]) are comparable with the range of 10-15 found for oligotrophic seawaters (Wilhelm et al. 1998, Hwang and Cho 2002b [burst sizes in those studies were estimated using the same method employed in the study reported here]). Such low burst sizes are probably associated with the low metabolic activities of bacteria in oligotrophic environments (Parada et al. 2006).

Virus-infected bacteria were also detected in the mesopelagic zone as frequently as those in the epipelagic zone of the study area. The mesopelagic frequency of visibly infected cells values in our study $(1.1 \% \pm 0.4 \%)$ were comparable with those observed for the Chukchi Sea $(0.4 \%-1.0 \%, 200$ to $400 \mathrm{~m}$ [Steward et al. 1996]), the East Sea (0.9\%$1.1 \%, 300$ to $500 \mathrm{~m}, n=6$ [C.Y.H., unpubl. data), and the Mediterranean Sea (0.6\%$0.8 \%, 100$ to $<800 \mathrm{~m}$ [Weinbauer et al. 2003]). Those results, together with this study, confirm that viruses may play an important role in the loss of bacterial production in mesopelagic environments.

It is interesting that a subsurface fre- 
quency of visibly infected cells peak was observed in the mesopelagic zone at each station (Figure 1). The subsurface peak was distinctly deeper at Stn. $4(1,000 \mathrm{~m})$ than at other stations (500 m [Figure 1]). Coincidently, there were hydrothermal vents (1,650-1,750 m depth) near Stn. $4(<10 \mathrm{~km}$ [Lee 2003]). However, during the cruise hydrothermal vents were not found near Stn. 5, and hydrothermal activity near Stn. 1 was not reported (Lee 2003). In our data, there was no clear indication of influence of hydrothermal activities at 1,000 m depth at Stn. 4 . Considering that hydrothermal venting can influence a far-greater region than the area immediately around the vent fields through the formation of a plume (several to tens of kilometers [Ortmann and Suttle 2005]), the possibility cannot be excluded that the elevated frequency of visibly infected cells value $(1.8 \%)$ found at $1,000 \mathrm{~m}$ depth at Stn. 4 could be affected by hydrothermal activity.

Another interesting aspect of the frequency of visibly infected cells data was that the frequency of visibly infected cells values $(1.7 \% \pm 0.1 \%)$ in the mixed layer at Stn. 5 occupied at midnight were significantly higher (ANOVA, $F=8.4$; $\mathrm{df}=2,6 ; P=.018$ ) than those at other stations $(0.8 \%-1.3 \%$ [Figure 1]) occupied during the day. The results of these frequency of visibly infected cells data are consistent with a previous observation that the frequency of infected cells showed a diel variation, with high values during the night and low values during the day (Winter et al. 2004). Frequency of dividing cells data for the mixed layer obtained from our study were also consistent with a diel study in which high bacterial activity was found during the day and low bacterial activity at night (Winter et al. 2004). Thus, diel variations in virusinfected bacteria and bacterial growth may exist in the equatorial ocean as well as in temperate seas.

To compare bacterial abundance and viral abundance data with previous studies of the equatorial Pacific, both time of day of sampling (for mixed-layer samples) and storage conditions (including storage time) must be considered. However, in our study, significant differences in bacterial abundance $(t$-test, $t=1.6, \mathrm{df}=7, P=.16)$ and viral abundance (t-test, $t=-2.3, \mathrm{df}=7, P=.058)$ in the mixed layer between night and day stations were not observed (within a twofold variation); similarly, Winter et al. (2004) reported that bacterial abundance and viral abundance did not show diel variations (varied within $\sim$ twofold). Thus, small (<twofold) differences in bacterial abundance and viral abundance between studies would not be meaningful, and the time of day of sampling was not considered in the following comparisons. Nagata et al. (2000) reported that depth-averaged bacterial abundances were $4.9 \times 10^{8}$ cells liter $^{-1}(0-100 \mathrm{~m})$ and $0.7 \times$

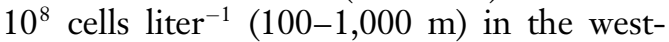
ern equatorial Pacific, based on conversion of their biomass data to cell numbers using their conversion factor of $15 \mathrm{fg} C$ cell $^{-1}$. Although information on storage conditions was not available for Nagata et al. (2000), our measurements of bacterial abundance $\left(5.0 \pm 0.7 \times 10^{8}\right.$ cells liter $^{-1}[0-100 \mathrm{~m}]$ and $0.7 \pm 0.2 \times 10^{8}$ cells liter $\left.^{-1}[100-1,000 \mathrm{~m}]\right)$ were similar to the values in Nagata et al. (2000). However, bacterial abundance of the surface waters $\left(5.0-6.6 \times 10^{8}\right.$ cells liter $^{-1}$ [Figure 1]) in our study were higher than those observed in 1-3 $\mathrm{m}$ depth of the eastern equatorial Pacific (0.7-1.5 $\times 10^{8}$ cells liter $^{-1}$ [Wilhelm et al. 2003]). In contrast, our measurements of viral abundance at $3 \mathrm{~m}$ depth $\left(0.9-1.7 \times 10^{9}\right.$ viruses liter $\left.^{-1}\right)$ were lower than those observed in $1-3 \mathrm{~m}$ depth of the eastern equatorial Pacific (3.8-7.1 $\times 10^{9}$ viruses liter $^{-1}$ [Wilhelm et al. 2003]). These discrepancies in bacterial abundance and viral abundance in the western and eastern equatorial Pacific might be caused by geographically different trophic status, because a similar preservation method (samples were preserved with fixative and stored at $4{ }^{\circ} \mathrm{C}$ ) and storage time ( $\sim$ month) were employed in both studies. Finally, it should be noted that viral abundance would substantially decrease to $32 \%$ of the initial viral abundance after 16 days (Wen et al. 2004) or to $31 \%-70 \%$ of the initial viral abundance after $\sim 1$ month (Hwang and Cho 2008) under similar preservation/storage conditions. Considering that viral abundance determined by epifluores- 
cence microscopy might be somewhat lower $(11 \%-34 \%)$ than that determined by flow cytometry, due to the limited resolution of epifluorescence microscopy compared with flow cytometry (Marie et al. 1999), the in situ viral abundance in our study and in Wilhelm et al. (2003) could be underestimated by at least 1.6-fold, due to both long-term storage and the employed methodology (epifluorescence microscopy).

Our study of the western equatorial Pacific confirmed that viruses are likely an important factor in the loss of bacterial production $(4.5 \%-20.8 \%)$ in oligotrophic seawaters. Inferred virally induced bacterial mortality is similar between epipelagic $(4.5 \%-20.8 \%)$ and mesopelagic $(5.0 \%-21.2 \%)$ zones, indicating that the viral loop is likely as active in the mesopelagic microbial food web as in the epipelagial. Possibly, in the mesopelagic zone of the study area, where substantially lower numbers of bacteria and viruses persist than in the epipelagic zone, lysogeny could be responsible for supporting the viral community, as in the oligotrophic Mediterranean Sea (Weinbauer et al. 2003).

\section{ACKNOWLEDGMENTS}

We thank two anonymous reviewers for their insightful and helpful comments, which greatly improved our manuscript. We thank S. M. Lee for providing us with the opportunity to join the cruise and D. S. Hahm for CTD data. We thank the crews and captain of RV Onnuri, Korea Ocean Research and Development Institute, for their excellent cooperation during the cruise.

\section{Literature Cited}

Binder, B. 1999. Reconsidering the relationship between virally induced bacterial mortality and frequency of infected cells. Aquat. Microb. Ecol. 18:207-215.

Brum, J. R. 2005. Concentration, production and turnover of viruses and dissolved DNA pools at Stn ALOHA, North Pacific Subtropical Gyre. Aquat. Microb. Ecol. 41:103-113.
Cho, B. C., and F. Azam. 1988. Major role of bacteria in biogeochemical fluxes in the ocean's interior. Nature (Lond.) 332:441443.

Cho, B. C., S. C. Na, and D. H. Choi. 2000. Active ingestion of fluorescently labeled bacteria by mesopelagic heterotrophic nanoflagellates in the East Sea, Korea. Mar. Ecol. Prog. Ser. 206:23-32.

Fuhrman, J. A. 1999. Marine viruses and their biogeochemical and ecological effects. $\mathrm{Na}$ ture (Lond.) 399:541-548.

Guixa-Boixareu, N., D. Vaqué, J. M. Gasol, and C. Pedrós-Alió. 1999. Distribution of viruses and their potential effect on bacterioplankton in an oligotrophic marine system. Aquat. Microb. Ecol. 19:205-213.

Hwang, C. Y., and B. C. Cho. 2002a. Uneven growth and different susceptibility to viruses among bacteria increase estimates of virus production in the East Sea based on TEM observation. Aquat. Microb. Ecol. 27:211-218.

2002b. Virus-infected bacteria in oligotrophic open waters of the East Sea, Korea. Aquat. Microb. Ecol. 30:1-9.

2008. Effects of storage on the estimates of virus-mediated bacterial mortality based on observation of preserved seawater samples with TEM. Aquat. Microb. Ecol. 52:263-271.

Karner, M. B., E. F. DeLong, and D. M. Karl. 2001. Archaeal dominance in the mesopelagic zone of the Pacific Ocean. Nature (Lond.) 409:507-510.

Lee, S. M. 2003. Multidisciplinary investigation of the western Pacific. Korea Ocean Research and Development Institute, Ansan [in Korean].

Marie, D., C. P. D. Brussaard, R. Thyrhaug, G. Bratbak, and D. Vaulot. 1999. Enumeration of marine viruses in culture and natural samples by flow cytometry. Appl. Environ. Microbiol. 65:45-52.

Morita, R. Y. 1997. Oligotrophic environments: Problems and concepts. Pages 135 in R. Y. Morita, ed. Bacteria in oligotrophic environments. Chapman and Hall, New York.

Nagata, T., H. Fukuda, R. Fukuda, and I. Koike. 2000. Bacterioplankton distribution 
and production in deep Pacific waters: Large-scale geographic variations and possible coupling with sinking particle fluxes. Limnol. Oceanogr. 45:426-435.

Noble, R. T., and J. A. Fuhrman. 1998. Use of SYBR Green I for rapid epifluorescence counts of marine viruses and bacteria. Aquat. Microb. Ecol. 14:113-118.

Noble, R. T., and G. F. Steward. 2001. Estimating viral proliferation in aquatic samples. Pages 67-83 in J. H. Paul, ed. Methods in microbiology. Vol. 30. Marine microbiology. Academic Press, London.

Ortmann, A. C., and C. A. Suttle. 2005. High abundances of viruses in a deep-sea hydrothermal vent system indicates viral mediated microbial mortality. Deep-Sea Res. I 52:1515-1527.

Parada, V., G. J. Herndl, and M. G. Weinbauer. 2006. Viral burst size of heterotrophic prokaryotes in aquatic systems. J. Mar. Biol. Assoc. U. K. 86:613-621.

Proctor, L. M., and J. A. Fuhrman. 1991. Roles of viral infection in organic particle flux. Mar. Ecol. Prog. Ser. 69:133-142.

Proctor, L. M., A. Okubo, and J. A. Fuhrman. 1993. Calibrating estimates of phageinduced mortality in marine bacteria: Ultrastructure studies of marine bacteriophage development from one-step growth experiments. Microb. Ecol. 25:161-182.

Shiah, F. K., S. J. Kao, and K. K. Liu. 1998. Bacterial production in the western equatorial Pacific: Implications of inorganic nutrient effects on dissolved organic carbon accumulation and consumption. Bull. Mar. Sci. 62:795-808.

Simon, M., N. A. Welschmeyer, and D. L. Kirchman. 1992. Bacterial production and the sinking flux of particulate organic matter in the subarctic Pacific. Deep-Sea Res. I 39:1997-2008.

Steward, G. F., D. C. Smith, and F. Azam. 1996. Abundance and production of bacteria and viruses in the Bering and Chukchi seas. Mar. Ecol. Prog. Ser. 131:287300.

Suttle, C. A. 1993. Enumeration and isolation of viruses. Pages 127-129 in P. F. Kemp, B. F. Sherr, E. B. Sherr, and J. J. Cole, eds. Handbook of methods in aquatic mi- crobial ecology. CRC Press, Boca Raton, Florida.

Tanaka, T., and F. Rassolzadegan. 2002. Full-depth profile $(0-2000 \mathrm{~m})$ of bacteria, heterotrophic nanoflagellates and ciliates in the NW Mediterranean Sea: Vertical partitioning of microbial trophic structures. Deep-Sea Res. 49:2093-2107.

Torréton, J. P., and P. Dufour. 1996. Bacterioplankton production determined by DNA synthesis, protein synthesis, and frequency of dividing cells in Tuamotu atoll lagoons and surrounding ocean. Microb. Ecol. 32:185-202.

Tuomi, P., K. M. Fagerbakke, G. Bratbak, and M. Heldal. 1995. Nutritional enrichment of a microbial community: The effects on activity, elemental composition, community structure and virus production. FEMS Microbiol. Ecol. 16:123-134.

Weinbauer, M. G. 2004. Ecology of prokaryotic viruses. FEMS Microbiol. Rev. 28: 127-181.

Weinbauer, M. G., I. Brettar, and M. G. Höfle. 2003. Lysogeny and virus-induced mortality of bacterioplankton in surface, deep, and anoxic marine waters. Limnol. Oceanogr. 48:1457-1465.

Weinbauer, M. G., D. Fuks, and P. Peduzzi. 1993. Distribution of viruses and dissolved DNA along a coastal trophic gradient in the northern Adriatic Sea. Appl. Environ. Microbiol. 59:4074-4082.

Weinbauer, M. G., C. Winter, and M. G. Höfle. 2002. Reconsidering transmission electron microscopy based estimates of viral infection of bacterioplankton using conversion factors derived from natural communities. Aquat. Microb. Ecol. 27: $103-110$.

Wen, K., A. C. Ortmann, and C. A. Suttle. 2004. Accurate estimation of viral abundance by epifluorescence microscopy. Appl. Environ. Microbiol. 70:3862-3867.

Wilhelm, S. W., W. H. Jeffrey, A. L. Dean, J. Meador, J. D. Pakulski, and D. L. Mitchell. 2003. UV radiation induced DNA damage in marine viruses along a latitudinal gradient in the southeastern Pacific Ocean. Aquat. Microb. Ecol. 31:1-8.

Wilhelm, S. W., M. G. Weinbauer, C. A. 
Suttle, and W. H. Jeffrey. 1998. The role of sunlight in the removal and repair of viruses in the sea. Limnol. Oceanogr. 43:586-592.

Winter, C., G. J. Herndl, and M. G. Weinbauer. 2004. Diel cycles in viral infection of bacterioplankton in the North Sea. Aquat. Microb. Ecol. 35:207-216.

Wommack, K. E., and R. R. Colwell. 2000. Virioplankton: Viruses in aquatic ecosystems. Microbiol. Mol. Biol. Rev. 64:69114. 